\title{
Symptom Screening in Pediatrics
}

National Cancer Institute

\section{Source}

National Cancer Institute. Symptom Screening in Pediatrics. NCI Thesaurus. Code

C156105.

A self-report screening tool, originally developed by Tomlinson et al. in 2013, that is used for symptom assessment in children with cancer and pediatric hematopoietic stem cell transplantation recipients. 